\title{
Mid-West Summer Weather and the Way of Least Friction
}

\section{Kern E. Kenyon}

4632 North Lane, Del Mar, USA

Correspondence to: Kern E. Kenyon, kernken@aol.com Keywords: Mid-West Summer Weather, Way of Least Friction

Received: July 26, $2020 \quad$ Accepted: September 12, $2020 \quad$ Published: September 15, 2020

Copyright $\odot 2020$ by author(s) and Scientific Research Publishing Inc.

This work is licensed under the Creative Commons Attribution International License (CC BY 4.0). http://creativecommons.org/licenses/by/4.0/

\section{(c) (i) Open Access}

\section{ABSTRACT}

\begin{abstract}
A typical summer weather event in the mid-west starts with a cool dry wind moving south near the Rocky Mountains and an equal mass of warm moist air moving north to the east of it in a side by side arrangement. Arguments supporting this proposition include observations, theory and one assumption. Observations are an awareness of the predominately north/south wind directions at one point in northwest Iowa for more than 30 consecutive summers as well as knowledge of the eastward flourishing vegetation distribution throughout the mid-west starting at the Rockies. The theory is the expectation that in geophysical flows the configuration most likely to persist and be observed has the least amount of friction among all possibilities. One assumption is that only a single southward cold wind takes place at one time to initiate the weather "cycle".
\end{abstract}

\section{INTRODUCTION}

Weather forecasts for the mid-west in summer are notoriously not accurate, which is a bit of a puzzle. If a storm could be tracked from the west coast to Iowa, for example, the situation would be much better, of course. But that does not happen. In summer the North Pacific High Pressure Cell (NPH) swells in size and intensity filling the whole ocean basin [1]. Then all ocean storms are effectively shut out from crossing into the US through the west coast.

That is not to say that there are no summer storms in the mid-west. Amazing incidences of quite violent weather commonly take place during the summer. These storms involve the interactions between opposing air flows: warm moist winds going north and cool dry winds going south. At one location in northwest Iowa the striking alternation of south and north winds all summer has been noticed for more than 30 years [2].

While slowly drifting eastward it is self-evident that the north and south winds accomplish a requirement of the atmosphere in the middle of the continent east of the Rockies: the heat balance. There must be a net transport of heat, absorbed from the sun, from low to high latitudes [2]. A side issue here is that there is also a net transport of water northward which falls as rain and returns south in the system of rivers. 
There are apparently very many different ways the winds could satisfy the heat balance requirement, including one way that would probably have made life easier for the forecaster. Suppose the cold air goes south along the ground and the warm air goes north on top in a two-layer arrangement. Being hydrostatically stable, this model would seem to have a chance of being maintained. However, experience implies that it never happens. At a point on the ground rain comes first and cold air comes second, not the other way around.

Through reasoning based on theory, evidence related to observations, and one assumption, the overall complexity of the mid-west summer weather situation is greatly reduced in the arguments below.

\section{WAY OF LEAST FRICTION}

Assume that the horizontal widths of the northward and southward winds are significantly greater than their vertical thicknesses, which is likely to be the case. Assume also that there is only one southward flow at a time. If true that greatly reduces the practical difficulties at hand, and it fits in with the idea of least friction. Then it stands to reason, when conservation of mass is included, that the surface area of interaction between oppositely directed flows is significantly smaller for the side by side configuration than it is for the two layer one. So what the winds are doing is consistent with the idea of the way of least friction being the one that allows the weather phenomenon to persist the longest and the one most likely to be observed.

Although the two layer wind system has just been eliminated from further discussion theoretically, and it does not appear to occur in nature anyway, the number and characteristics of side by side solutions to the heat balance problem remains to be assessed.

A summer weather "cycle" starts when relatively cold dry air in Canada bursts south because of the general instability set up by the sun and the earth's curvature: at the same level cold air in the north and warm air in the south is inherently unstable. It is an "accident" just waiting to happen. When the cold air burst takes place can occur any time of day or night, independent of the position of the sun locally. That is the key uncertainty in the whole situation. Other variables are the width and duration of the southward cold dry winds.

For the location of the southward burst of cold dry air long term averages of vegetation suggest that the odds are that it is near the Rockies [3]. East/west transects in the US from North Dakota to Texas show grass, bushes and trees getting thicker and taller as one travels east. Somewhere between Nebraska and Iowa there is a change. For example, in Nebraska the corn is shorter even though it is irrigated, and in Iowa it is taller without irrigation. Rain occurs when the south moist winds interact side by side with the dry north winds. Consequently the yearly and long term vegetation distributions imply that the amount of rain falling in summer increases eastward from the Rockies. Presumably the northward warm and humid winds rarely if ever make their presence felt close to the Rockies, because the cold dry winds are there already.

\section{DISCUSSION}

Help for the summer forecaster in the mid-west may come from starting to look more to the north, because looking far to the west is not useful at this time of year. What may be of advanage to them is to know when, no matter the day or time of day, the cold dry southward wind starts up, as well as how long it continues. The farther north the weather stations are that do this reporting the better, and their locations should be within several hundred miles east of the Rockies.

In some other geophysical applications of the idea of least friction [4] there are a few in which "least" would be zero in the ideal case. Two of these are the hurricane and the tornado, where in both examples the theoretical radial velocity structure has zero friction according to the Navier-Stokes equations.

\section{CONCLUSION}

In summary and in general, the summer weather ball is set rolling by a cold blast of dry air going 
south near the Rockies. It is caused by an instability and can happen at any hour of the day. East of the south wind the same amount of air that is warm and moist heads north. The interaction between these two opposing winds in a side by side configuration produces rain where they contact each other. Then the whole system slowly drifts to the east. Similar "cycles" are repeated all summer long in the mid-west. This essay provides a framework for gathering more observational information.

\section{CONFLICTS OF INTEREST}

The author declares no conflicts of interest regarding the publication of this paper.

\section{REFERENCES}

1. Kenyon, K.E. (1999) North Pacific High: An Hypothesis. Atmospheric Research, 51, 15-34.

https://doi.org/10.1016/S0169-8095(98)00110-0

2. Kenyon, K.E. (2013) Northward Heat Flux in Mid-West Summers. International Journal of Geosciences, 4.

3. Kenyon, K.E. (2019) Mid-West Growing Season Weather. International Journal of Geosciences, 10, 1128-1131. https://doi.org/10.4236/ijg.2019.1012064

4. Kenyon, K.E. (2019) Bernoulli Loops with No Friction. European International Journal of Science and Technology, 8. 